\title{
Article \\ The Promotion of Festuca sinensis under Heavy Metal Treatment Mediated by Epichlö̈ Endophyte
}

\author{
Meining Wang, Pei Tian *, Min Gao and Miaomiao Li
}

Citation: Wang, M.; Tian, P.; Gao, M.; Li, M. The Promotion of Festuca sinensis under Heavy Metal Treatment Mediated by Epichloë Endophyte. Agronomy 2021, 11, 2049. https:// doi.org/10.3390/agronomy11102049

Academic Editor: Chao Zhang

Received: 5 September 2021

Accepted: 8 October 2021

Published: 12 October 2021

Publisher's Note: MDPI stays neutral with regard to jurisdictional claims in published maps and institutional affiliations.

Copyright: (c) 2021 by the authors. Licensee MDPI, Basel, Switzerland. This article is an open access article distributed under the terms and conditions of the Creative Commons Attribution (CC BY) license (https:// creativecommons.org/licenses/by/ $4.0 /)$.
State Key Laboratory of Grassland Agro-Ecosystems, Key Laboratory of Grassland Livestock Industry Innovation, Ministry of Agriculture and Rural Affairs, College of Pastoral Agriculture Science and Technology, Lanzhou University, Lanzhou 730020, China; wangmn16@lzu.edu.cn (M.W.); gaom2018@lzu.edu.cn (M.G.); limm16@lzu.edu.cn (M.L.)

* Correspondence: tianp@lzu.edu.cn; Tel.: +86-139-1995-3598

\begin{abstract}
To more clearly clarify the relationship between the Epichloë endophyte and its host, F. sinensis, the effects of Epichloë endophyte on F. sinensis performance under heavy metal treatment was investigated. The growth performance and physiology variations of $F$. sinensis with (E+) and without the endophyte (E-) were evaluated after they were subjected to $\mathrm{Zn}^{2+}$ and $\mathrm{Cd}^{2+}$ treatments. The results showed that heavy metal treatments had significant effects on plants, as the performance of plants under $\mathrm{Zn}^{2+}$ and $\mathrm{Cd}^{2+}$ treatments was significantly different with plants under control treatment $(p<0.05) . \mathrm{Cd}^{2+}$ treatments showed a hormesis effect, whereas $\mathrm{Zn}^{2+}$ did not. The endophyte increased host heavy metal stress tolerance by promoting host growth as the E+ plants had significantly higher plant height, tiller number, root length $(p<0.05)$. The endophyte also promoted ion uptake by the host and induced endogenous hormone production $(p<0.05)$. These results suggested that the Epichloë endophyte regulated host growth and physiology to improve association tolerance to environmental conditions. This study provides another example that the Epichloë endophyte can increase plant tolerance to metal stress.
\end{abstract}

Keywords: alkaloids; $\mathrm{Cd}^{2+}$ treatment; Epichloë sinensis; hormone; host growth; ion absorbing; $\mathrm{Zn}^{2+}$ treatment

\section{Introduction}

Festuca sinensis Keng ex E.B. Alexeev, is a native cool-season perennial grass species distributed across the cold and semi-arid regions of China. This species, grazed by cattle and sheep, is widely utilised in grassland production on the Qinghai-Tibet plateau of China [1,2]. It is also important for grassland establishment, restoration of degraded grassland and ecological management [3]. F. sinensis is frequently infected with an asexual, symptomless Epichloë species [4-8]. This endophyte has been isolated and identified by morphology with colony, texture, conidia and conidiophore, and phylogene with housekeeping gene, which confirmed that the strain is new species name after Epichloë sinensis [9]. Epichloë endophytes interact mutualistically with their host plant, mainly by enhancing the fitness of the grass host and protection from both biotic and abiotic stresses [10,11]. Research to reveal the relationship between F. sinensis and Epichloë endophytes showed that associations between F. sinensis and endophytes produce alkaloids [12], and endophyte could increase F. sinensis seed germination and seedling growth [13], competition in mixsowing grassland [14], enhance host cold-stress resistance [6,13], and improve host drought and waterlogged condition resistance [15]. However, the effects of the endophyte on host tolerance to other stress such as heavy metals and salt have not been clarified.

With the increasing industrialization of the global economy over the last century, heavy metals have been introduced into the environment and have caused extensive environmental problems [16]. Phytoremediation, the use of green plants to remove pollutants from the environment or to render them harmless, is an in situ, solar-powered remediation 
technology [17]. This technology can be used to clean up and/or stabilize heavy metal contaminants, and has been considered to be the most promising technology due to its minimal site disturbance and low cost when compared with conventional remediation methods [18]. Microbe-assisted phytoremediation is a novel and promising concept. So far, numerous studies have demonstrated that microorganisms can enhance phytoremediation efficiently [19]. Epichloë endophytes can also increase the host stress tolerance of heavy metals such as cadmium $\left(\mathrm{Cd}^{2+}\right)$, aluminum $\left(\mathrm{Al}^{3+}\right)$, zinc $\left(\mathrm{Zn}^{2+}\right)$ and copper $\left(\mathrm{Cu}^{2+}\right)$ tolerance [20-23]. However, the relationship between E. sinensis endophyte and $F$. sinensis under heavy metal stress is unknown. The aims of this study were to investigate the performances of $F$. sinensis - endophyte interactions under heavy metal treatment, and to evaluate the possibility of employing the $F$. sinensis - endophyte association for phytoremediation in heavy metal polluted soils.

\section{Materials and Methods}

\subsection{Plant Materials}

F. sinensis seeds were collected from endophyte infected (E+) or endophyte free (E-) plants in summer, 2016 in experimental field blocks $\left(104^{\circ} 39^{\prime} \mathrm{E}, 35^{\circ} 89^{\prime} \mathrm{N}\right.$, altitude $\left.1653 \mathrm{~m}\right)$ at the College of Pastoral Agriculture Science and Technology (CPAST), Yuzhong campus of Lanzhou University [12]. The plants were grown from seed collected in Hongyuan, Sichuang $\left(102^{\circ} 33^{\prime} \mathrm{E}, 32^{\circ} 48^{\prime} \mathrm{N}\right.$, altitude $\left.3491 \mathrm{~m}\right)$ in 2013 . Endophyte viability in seeds was assessed by aniline blue staining and microscopic examination [4]. After the seeds were treated with aniline blue solution, the sampled seed was marked as E+ if the longitudinallyorientated hyphae of the Epichloë endophyte were observed in the seed skin and aleuronic layer, and vice versa. After assessment, the seeds were stored in $4{ }^{\circ} \mathrm{C}$ until utilization. In August 2017, the well-filled, healthy-looking E+ and E- seeds were planted in plastic trays $(30 \mathrm{~cm} \times 25 \mathrm{~cm} \times 8 \mathrm{~cm}$ ) filled with $1.5 \mathrm{~kg}$ soil (commercial fine sandy soil, Lanzhou) which had been sterilized in an oven at $130{ }^{\circ} \mathrm{C}$ for $30 \mathrm{~min}$. Five rows with 10 seeds were planted per tray at a depth of $1 \mathrm{~cm}$. Two trays containing E+ and E- seeds were placed in a temperature-controlled greenhouse $\left(18-24{ }^{\circ} \mathrm{C}\right)$ with $10 \mathrm{~h}$ of illumination per day in the Yuzhong campus of Lanzhou University. After plants had 3 tillers, endophyte viability in $\mathrm{E}+$ and $\mathrm{E}$ - population seedlings were determined by microscopic examination of host leaf sheath pieces after they had been stained with aniline blue [5]. After the leaf sheaths were gently peeled from the tissue and treated with aniline blue solution, the sampled plants were marked as E+ if the longitudinally-orientated hyphae of the Epichloë endophyte were observed in the tissues, and vice versa. The seedlings germinated from E+ seeds with hyphae of the endophyte were marked as E+ and the seedlings germinated from E- seeds without hyphae were marked as E-.

\subsection{Experimental Design}

The marked seedlings were transplanted into round pots (upper diameter $15.5 \mathrm{~cm} \times$ lower diameter $11.5 \mathrm{~cm} \times$ height $14 \mathrm{~cm}$ ) containing the same amount of media (sterilized commercial vermiculite and black soil in a $w / w$ ratio 3:1) which fill the pot. Each pot had only one similar growth seeding and equal initial water treatment. After one-month stabilization with the same irrigation, three different treatments were established, which included control treatment $(\mathrm{CK}), \mathrm{Zn}^{2+}$ treatment $\left(\mathrm{Zn}, 500 \mathrm{mg} \cdot \mathrm{L}^{-1} \mathrm{ZnCl}_{2}\right)$ and $\mathrm{Cd}^{2+}$ treatment $\left(\mathrm{Cd}, 100 \mathrm{mg} \cdot \mathrm{L}^{-1} \mathrm{CdCl}_{2}\right)$. Each treatment has 5 replicates which were randomly placed in greenhouse maintained at a constant condition (temperature: $25 \pm 2{ }^{\circ} \mathrm{C}$, humidity: $42 \pm 5 \%$ ). During the experimental period, the plants under control treatment were supplied with $100 \mathrm{~mL}$ water every 3 days, $\mathrm{Zn}^{2+}$ and $\mathrm{Cd}^{2+}$ treatments were watered with $100 \mathrm{~mL} \mathrm{ZnCl} 2$ solution of $500 \mathrm{mg} \cdot \mathrm{L}^{-1}$ and $100 \mathrm{~mL} \mathrm{CdCl} 2$ solution of $100 \mathrm{mg} \cdot \mathrm{L}^{-1}$ at 1 st and 14th day, respectively, and $100 \mathrm{~mL}$ water were also supplied with every 3 interval days. 


\subsection{Experimental Evaluations}

2.3.1. Determination of Endogenous Phytohormones

After 28 days growth, $2 \mathrm{~g}$ of fresh leaves were collected from each plant for gibberellin $\left(\mathrm{GA}_{3}\right)$, indole-3-acetic acid (IAA), cytokinins (CTK) and abscisic acid (ABA) content tests using enzyme-linked immunosorbent assays, following the procedure of kits which included extraction with phosphate-buffered saline ( $\mathrm{pH}$ 7.4), coating the corresponding antibody of each phytohormones, blocking and detection at $450 \mathrm{~nm}$ (Danshi biology, Shanghai, China) [24].

\subsubsection{Plant Growth}

The whole plants were destructively harvested from pots after 28 days growth, washed with distilled water and dried on a filter paper. The height, root length and tiller number of each plant were recorded. All harvested plants were separated into roots and shoots and their fresh weight was recorded. Dry weight was obtained after oven-drying at $60^{\circ} \mathrm{C}$ until a constant weight was reached. The dry aboveground and underground parts from each treatment were weighed separately to determine total dry matter per plant. After weighting, the plant materials were ground twice using a mixer mill (Retch $400 \mathrm{MM}$, German) at $30 \mathrm{~Hz}$ for $2 \mathrm{~min}$ for analysis of alkaloid, $\mathrm{Zn}^{2+}$ and $\mathrm{Cd}^{2+}$ ion contents.

\subsubsection{Measurements of $\mathrm{Zn}^{2+}$ and $\mathrm{Cd}^{2+}$ Ions Concentrations}

$\mathrm{Zn}^{2+}$ and $\mathrm{Cd}^{2+}$ concentrations in plants were analysed using atomic absorption spectrometry (M6AA system, Thermo, Waltham, MA, USA) at 213.9 and $228.8 \mathrm{~nm}$, respectively, after mineralization in mixture of acids $\left(\mathrm{HCl}-\mathrm{HNO}_{3}-\mathrm{HF}-\mathrm{HClO}_{4}\right)[25,26]$.

The translocation factor (TF) is the concentration ratio of metal acclimatised in the shoot to that present in the root.

$$
\mathrm{TF}=\mathrm{C}_{\text {shoot }} / \mathrm{C}_{\text {root }}
$$

where Cshoot $\left(\mathrm{mg} \cdot \mathrm{kg}^{-1}\right)$ and Croot $\left(\mathrm{mg} \cdot \mathrm{kg}^{-1}\right)$ represent the metal concentration in the shoot and root, respectively [27].

\subsubsection{Measurements of Alkaloid Concentrations}

Concentrations of peramine and lolitrems B were measured using high performance liquid chromatography (HPLC) [28,29].

\subsection{Statistical Analyses}

All averages and standard errors of the difference (SE) of measurements were recorded in Excel software, and statistical analysis was performed using SPSS software (version 18.0, Chicago, IL, USA). After a Kolmogorov-Smirnov test for normality and one-way ANOVA for descriptive and test homogeneity of variance, a two-way ANOVA at the $95 \%$ confidence level was used to estimate the effects of endophyte and heavy metal treatments on host plants. A repeated-measures ANOVA with Fisher's least significant differences (LSD) test was used to determine whether differences between means were statistically significant.

\section{Results}

\subsection{Plant Growth}

Both heavy metal treatments and endophytes had significant effects on plant growth (Figures 1-3) and plant physiology (Figures 4-7).

The plant height (Figures $1 \mathrm{~A}$ and 2 ) and tiller numbers (Figures $1 \mathrm{~B}$ and 2 ) of the E+ plants were significantly higher $(p<0.05)$ than those of E- plants under two heavy metal $\left(\mathrm{Zn}^{2+}\right.$ and $\left.\mathrm{Cd}^{2+}\right)$ treatments and control (except for tiller numbers). The heavy metal treatments had significant effects on plant height (Figure 1A). For both the E+ and Eplants, the plant height was highest under $\mathrm{Zn}^{2+}$ treatment and lowest under $\mathrm{Cd}^{2+}$ treatment 
$(p<0.05)$. However, heavy metal treatments had no significant effects on tiller numbers for both E+ and E- plants (Figure 1B).

The root length of E+ plants was significantly higher $(p<0.05)$ than that of $\mathrm{E}-$ plants under control and $\mathrm{Zn}^{2+}$ treatments (Figure 3A). Heavy metal treatments only had significant effects on the root length of the $\mathrm{E}+$ plants as the $\mathrm{E}+$ plants had significantly longer root length under control and $\mathrm{Zn}^{2+}$ treatments than that under $\mathrm{Cd}^{2+}$ treatment. The plant biomass (Figure 3B) of E+ plants was significantly higher $(p<0.05)$ than those of $\mathrm{E}$ - plants under $\mathrm{Zn}^{2+}$ treatment. For both the E+ and E- plants, the plant biomass was highest under $\mathrm{Zn}^{2+}$ treatment and lowest under $\mathrm{Cd}^{2+}$ treatment $(p<0.05)$.
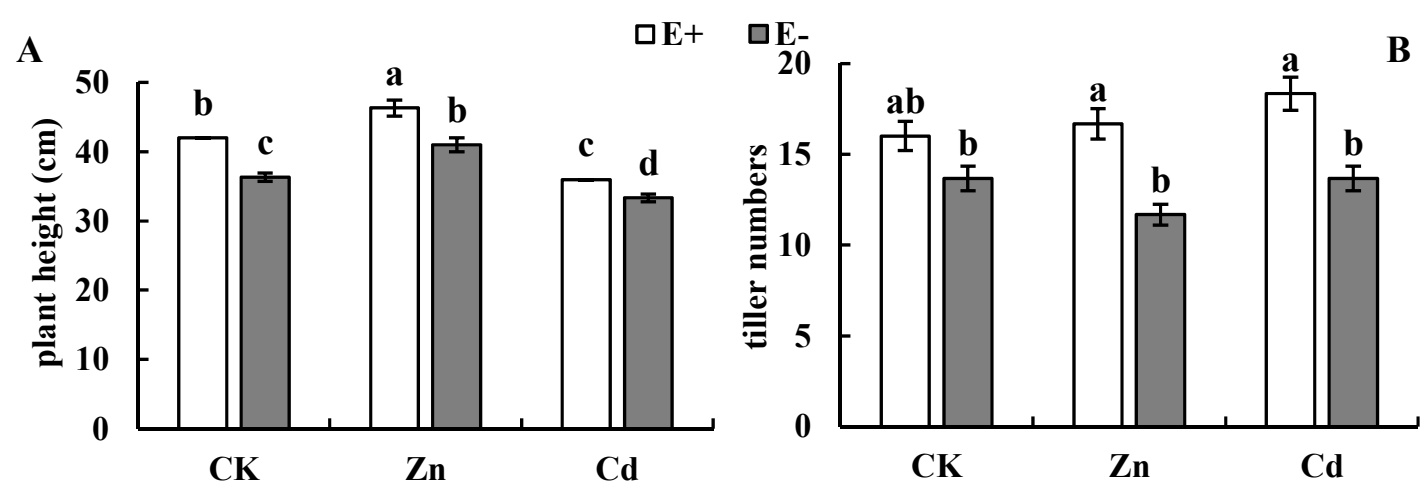

Figure 1. Effect of Epichloë endophyte and $\mathrm{Cd}^{2+}$ and $\mathrm{Zn}^{2+}$ treatments on plant height (A) and tiller number (B) of $F$. sinensis. Note: Different lowercase letters indicate significant differences between treatments $(p<0.05)$.

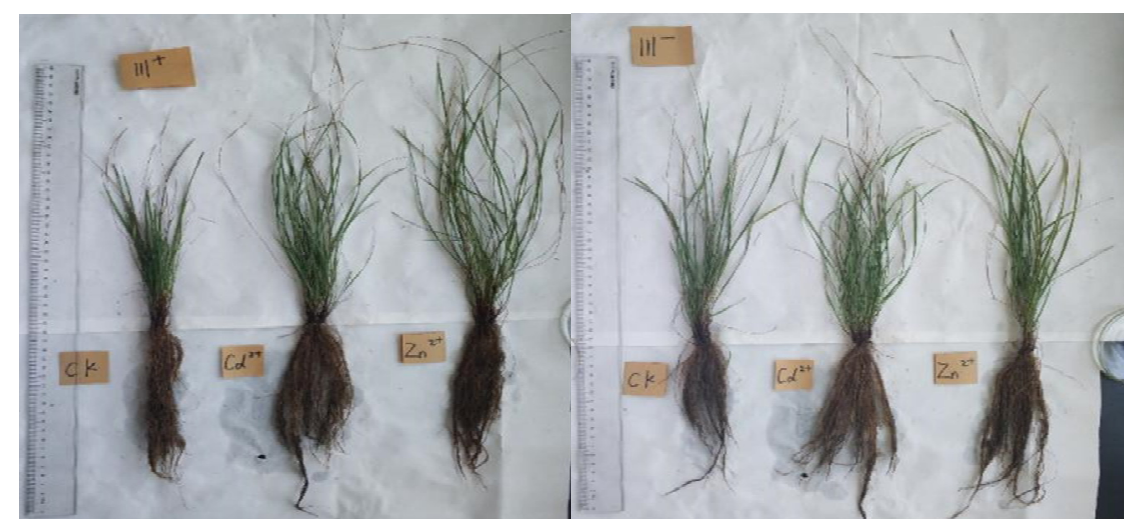

Figure 2. Photos showing comparative phenotypes of E+ and E- plants under different treatments after harvesting.
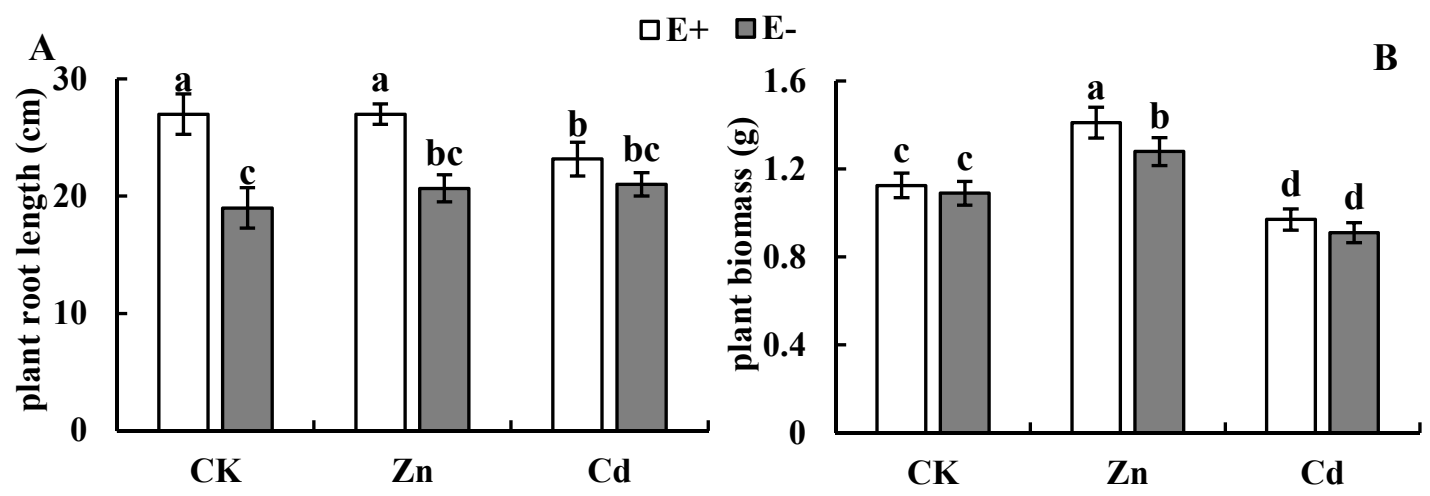

Figure 3. Effects of Epichloë endophyte and $\mathrm{Cd}^{2+}$ and $\mathrm{Zn}^{2+}$ treatments on plant root length (A) and biomass (B) of F. sinensis. Note: Different lowercase letters indicate significant differences between treatments $(p<0.05)$. 


\section{2. $\mathrm{Cd}^{2+}$ and $\mathrm{Zn}^{2+}$ Ion Concentration}

Both the aboveground (Figure $4 \mathrm{~A}$ ) and underground (Figure 4B) $\mathrm{Cd}^{2+}$ ion concentrations were significantly higher $(p<0.05)$ in $\mathrm{E}+$ plants than those in $\mathrm{E}-$ plants under $\mathrm{Cd}^{2+}$ treatment. For both $\mathrm{E}+$ and $\mathrm{E}-$ plants, aboveground and underground $\mathrm{Cd}^{2+}$ ion concentrations were significantly higher $(p<0.05)$ under $\mathrm{Cd}^{2+}$ treatment than those under control and $\mathrm{Zn}^{2+}$ treatments.
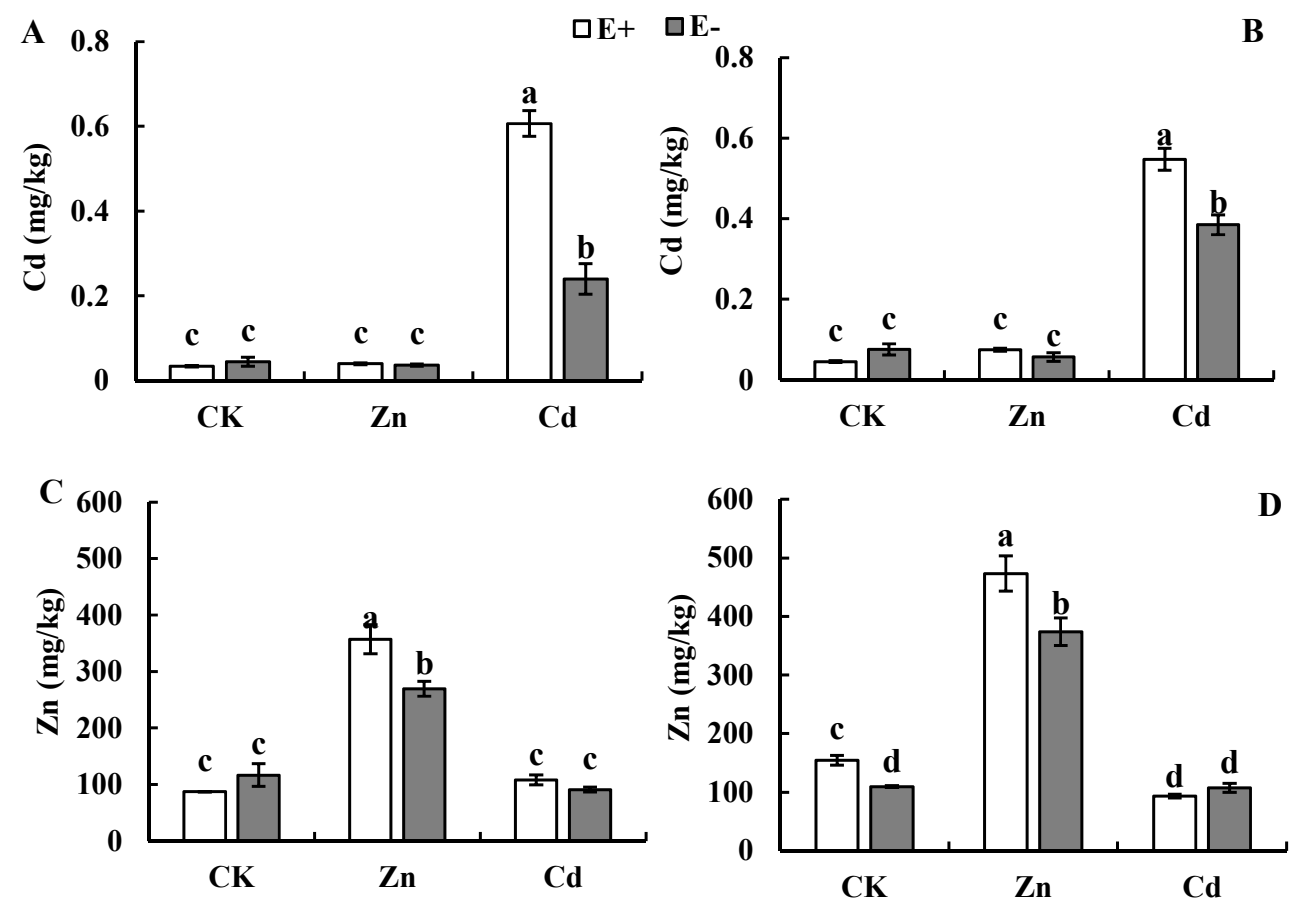

Figure 4. Effect of Epichloë endophyte and $\mathrm{Cd}^{2+}$ and $\mathrm{Zn}^{2+}$ treatments on the aboveground and underground concentration of $\mathrm{Cd}^{2+}$ and $\mathrm{Zn}^{2+}$ ions in F. sinensis; (A) aboveground $\mathrm{Cd}^{2+}$ ions, (B) underground $\mathrm{Cd}^{2+}$ ions, $(\mathbf{C})$ aboveground $\mathrm{Zn}^{2+}$ ions, (D) underground $\mathrm{Zn}^{2+}$ ions. Note: Different lowercase letters indicate significant differences between treatments $(p<0.05)$.

The aboveground $\mathrm{Zn}^{2+}$ ion concentration (Figure 4C) of E+ plants was significantly higher $(p<0.05)$ than that of $\mathrm{E}-$ plants only under $\mathrm{Zn}^{2+}$ treatment. For both $\mathrm{E}+$ and $\mathrm{E}-$ plants, aboveground $\mathrm{Zn}^{2+}$ ion concentration were significantly higher under $\mathrm{Zn}^{2+}$ treatment than that under the control and $\mathrm{Cd}^{2+}$ treatments. The underground $\mathrm{Zn}^{2+}$ ion concentrations (Figure $4 \mathrm{D}$ ) of $\mathrm{E}+$ plants were significantly higher $(p<0.05)$ than that of $\mathrm{E}-$ plants under control and $\mathrm{Zn}^{2+}$ treatments. For $\mathrm{E}+$ plant, the underground $\mathrm{Zn}^{2+}$ ion concentrations were highest under $\mathrm{Zn}^{2+}$ treatment and lowest under $\mathrm{Cd}^{2+}$ treatment $(p<0.05)$. For E- plants, the underground $\mathrm{Zn}^{2+}$ ion concentrations were significant higher under $\mathrm{Zn}^{2+}$ treatment than under control and $\mathrm{Cd}^{2+}$ treatments. There was no significant difference in the underground $\mathrm{Zn}^{2+}$ ion concentrations between the control and $\mathrm{Cd}^{2+}$ treatments.

The TF values of the $\mathrm{Zn}^{2+}$ and $\mathrm{Cd}^{2+}$ ions ranged from $0.56-1.16$ (Figure $5 \mathrm{~A}, \mathrm{~B}$ ). The $\mathrm{TF}$ value of the $\mathrm{Zn}^{2+}$ ions (Figure $5 \mathrm{~A}$ ) of $\mathrm{E}+$ plants were significantly higher $(p<0.05)$ than those of $\mathrm{E}-$ plants under $\mathrm{Cd}^{2+}$ treatment, whereas they were significantly lower $(p<0.05)$ than those of $\mathrm{E}-$ plants under the control treatment. For E+ plants, the TF values of the $\mathrm{Zn}^{2+}$ ions were highest under $\mathrm{Cd}^{2+}$ treatment and lowest under the control treatment $(p<0.05)$. For $\mathrm{E}-$ plants, the TF values of the $\mathrm{Zn}^{2+}$ ions were significantly higher under control treatment than that under the $\mathrm{Zn}^{2+}$ and $\mathrm{Cd}^{2+}$ treatments $(p<0.05)$. The TF values of the $\mathrm{Cd}^{2+}$ ions (Figure 5B) of the $\mathrm{E}+$ plants were significantly higher $(p<0.05)$ than that of $\mathrm{E}$ - plants only under $\mathrm{Cd}^{2+}$ treatment. For the $\mathrm{E}+$ plant, the TF value of the $\mathrm{Cd}^{2+}$ ions weres highest under $\mathrm{Cd}^{2+}$ treatment $(p<0.05)$. For the $\mathrm{E}-$ plant, there was no significant difference in the TF value of the $\mathrm{Cd}^{2+}$ ions between these three treatments $(p<0.05)$. 

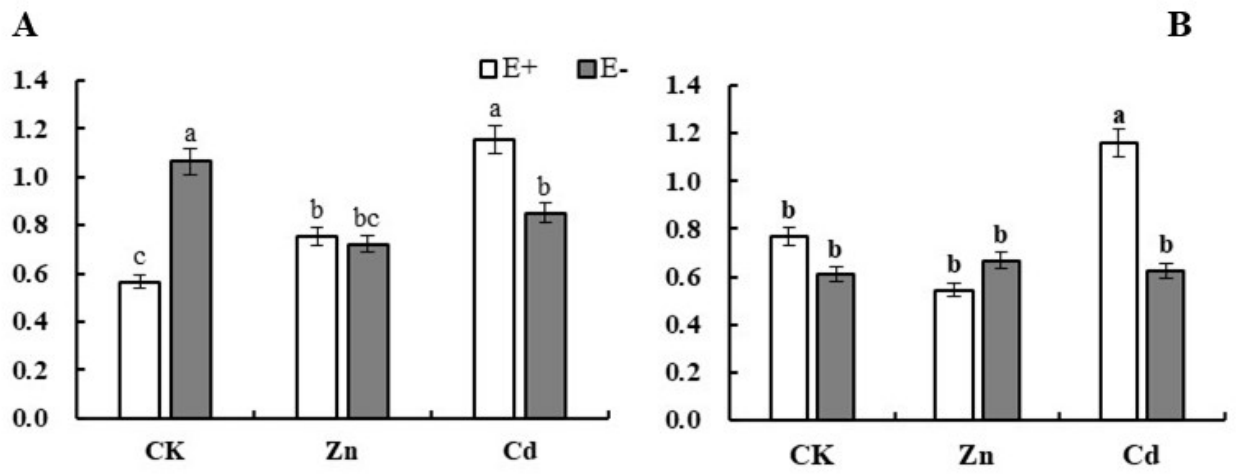

Figure 5. Effect of Epichloë endophytes and $\mathrm{Cd}^{2+}$ and $\mathrm{Zn}^{2+}$ treatments on TF values of $F$. sinensis; (A) TF values of $\mathrm{Zn}^{2+}$ ions; (B) TF values of $\mathrm{Cd}^{2+}$ ions. Different lowercase letters indicate significant differences between treatments $(p<0.05)$.

\subsection{Plant Hormone Concentrations}

$\mathrm{GA}_{3}$ concentrations (Figure 6A) in E+ plants were consistently higher $(p<0.05)$ than those in $\mathrm{E}$ - plants for all 3 treatments. For $\mathrm{E}+$ plants, $\mathrm{GA}_{3}$ concentrations were highest under $\mathrm{Zn}^{2+}$ treatment and lowest under $\mathrm{Cd}^{2+}$ treatment $(p<0.05)$. However, for $\mathrm{E}-$ plants, $\mathrm{GA}_{3}$ concentrations were highest under control treatment and lowest under $\mathrm{Cd}^{2+}$ treatment $(p<0.05)$. The CTK concentrations (Figure 6B) in E+ plants were consistently higher $(p<0.05)$ than those in E- plants for all 3 treatments. For both E+ and E- plants, CTK concentrations were highest under $\mathrm{Zn}^{2+}$ treatment and lowest under $\mathrm{Cd}^{2+}$ treatment $(p<0.05)$. The IAA concentrations (Figure 6C) in E+ plants were significantly higher $(p<0.05)$ than those in E- plants for all 3 treatments. For both E+ and E- plants, IAA concentrations under control and $\mathrm{Zn}^{2+}$ treatments were significantly higher $(p<0.05)$ than those under $\mathrm{Cd}^{2+}$ treatment. The ABA concentrations (Figure 6D) in E- plants were significantly higher $(p<0.05)$ than those in $\mathrm{E}+$ plants under $\mathrm{Zn}^{2+}$ treatment. For both $\mathrm{E}+$ and $\mathrm{E}-$ plants, $\mathrm{ABA}$ concentrations were highest under $\mathrm{Cd}^{2+}$ treatment and lowest under $\mathrm{Zn}^{2+}$ treatment $(p<0.05)$.
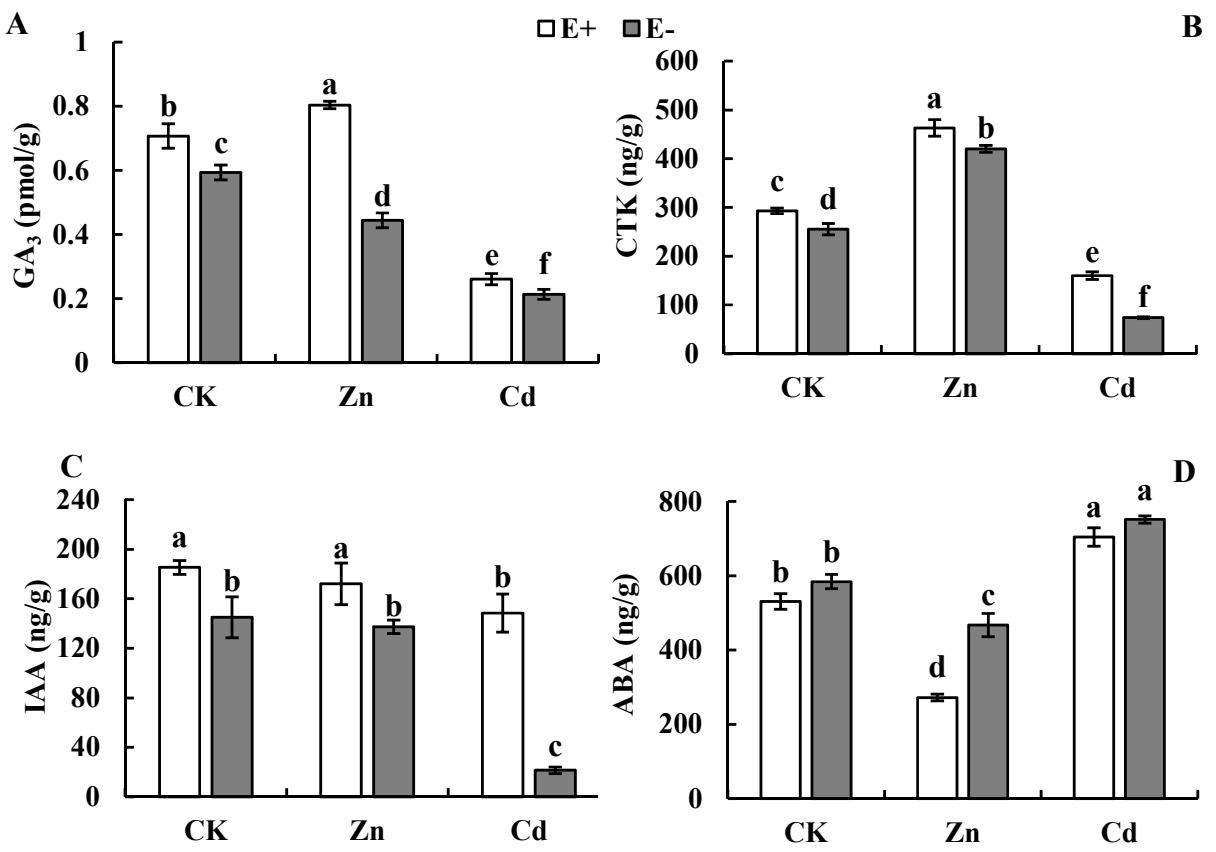

Figure 6. Effect of Epichloë endophytes and $\mathrm{Cd}^{2+}$ and $\mathrm{Zn}^{2+}$ treatments on the concentration of $\mathrm{GA}_{3}$ (A), CTK (B), IAA (C) and ABA (D) in F. sinensis. Note: Different lowercase letters indicate significant differences between treatments $(p<0.05)$. 


\subsection{Alkaloids}

$\mathrm{E}+$ plants produced both tested alkaloids: peramine and lolitrem B, while E- plants did not produce any alkaloids (Figure 7). The heavy metal treatments only had significant effects on lolitrem B concentrations. There was no significant difference in peramine concentrations among these 3 treatments. The lolitrem B concentrations under $\mathrm{Cd}^{2+}$ treatment were significantly higher than those under control and $\mathrm{Zn}^{2+}$ treatments.
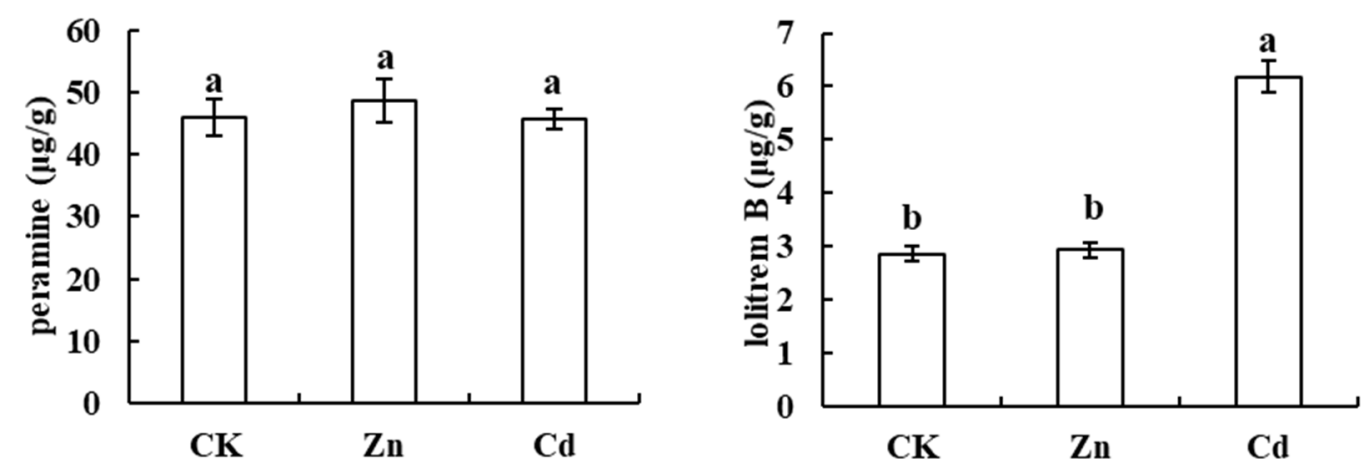

Figure 7. Peramine and lolitrem B concentrations of $F$. sinensis $\mathrm{E}+$ plants under $\mathrm{Zn}^{2+}$ and $\mathrm{Cd}^{2+}$ treatments. Note: The left is the alkaloid peak. Different lowercase letters indicate significant differences between treatments $(p<0.05)$.

\section{Discussion}

Excessive $\mathrm{Zn}^{2+}$ in soil will cause heavy metal pollution and reduce plant growth, although it is a necessary trace element for plant growth [30]. A previous study has shown that $300 \mathrm{mg} / \mathrm{L} \mathrm{Zn}^{2+}$ in soil inhibited tillering and leaf extension and reduced biomass of Achnatherum sibiricum [2]. Another study showed that $20 \mathrm{mg} / \mathrm{L} \mathrm{Zn}^{2+}$ promoted F. arundinacea seed germination and biomass accumulation, whereas $50 \mathrm{mg} / \mathrm{L} \mathrm{Z \textrm {Z } ^ { 2 + }}$ inhibited seed germination [31]. However, our study showed that plant height and biomass of $F$. sinensis under $500 \mathrm{mg} / \mathrm{L} \mathrm{Zn}^{2+}$ treatment significantly increased $(p<0.05)$ compared with control. The reason why this $\mathrm{Zn}^{2+}$ dosage did not show a hormesis effect in plants needs further clarification by a deeper characterization of the used soil such as organic matter content, soil $\mathrm{pH}$ and the actual bioavailability of zinc. $\mathrm{Cd}^{2+}$ is one of the heavy metals that is most toxic to plants. It disturbs plant physiological processes, including photosynthesis, respiration and nutrient element absorption, and seriously inhibits plant growth and development [32]. $\mathrm{Cd}^{2+}$ inhibited the germination and growth of $A$. inebrians, Elymus dahuricus and Hordeum brevisubulatum, leading to leaf yellowing, radicle browning and biomass reduction $[33,34] . \mathrm{Cd}^{2+}$ has a sustained inhibitory impact on seed germination and seedling growth of $A$. sibiricum [24]. The present study found that $100 \mathrm{mg} / \mathrm{L} \mathrm{Cd}^{2+}$ inhibited plant height and biomass accumulation, which were consistent with the findings of other studies that showed $\mathrm{Cd}^{2+}$ usually inhibited plant growth.

In the present study, Epichloë endophytes significantly increased plant height, tiller number and biomass of $F$. sinensis under $\mathrm{Zn}^{2+}$ treatment, and significantly increased tiller number and root growth under $\mathrm{Cd}^{2+}$ treatment. Similar results were also found from previous studies which suggested that endophytes increased host tolerance to heavy metals and alleviated the toxicity. Bonnet et al. also found that endophytes increased perennial ryegrass tolerance to $\mathrm{Zn}^{2+}$ with increased aboveground biomass [21]. Endophytes promoted the performance of Lolium perenne, F. arundinacea and A. sibiricum tillering under $\mathrm{Cd}^{2+}$ treatment $[2,22]$. Endophytes can alleviate the toxicity of $\mathrm{Cd}^{2+}$ to F. arundinacea and F. pratensis as E+ plants have more biomass than E- plants. Epichloë endophytes can also increase host heavy metal stress tolerances, such as $\mathrm{Cd}^{2+}, \mathrm{Al}^{3+}, \mathrm{Zn}^{2+}$ and $\mathrm{Cu}^{2+}[20-22]$.

In the present study, endophyte improved the uptake of $\mathrm{Zn}^{2+}$ and $\mathrm{Cd}^{2+}$ ions in plants which suggests that endophytes may not reduce the toxicity condition of host plants. Especially for the TF value of $\mathrm{Zn}^{2+}$ and $\mathrm{Cd}^{2+}$ ions under $\mathrm{Cd}^{2+}$ treatment, the values of $\mathrm{E}+$ plants were over 1 and also were significantly higher than E- plants, which showed 
that $\mathrm{Cd}^{2+}$ ion translocation from roots to shoots remained very high. This was consistent with the higher concentrations of $\mathrm{Cd}^{2+}$ ions in aboveground plants. The changes of ion absorption and distribution may have relationship with root exudates. Previous studies showed that endophytes improved the phenolic contents of F. arundinacea and A. sibiricum which reduced the toxicity of heavy metals [35-37]. Phenolics in root exudates of F. arundinacea could chelate with some heavy metal ions, which reduced heavy metal activity and toxicity [38]. However, endophytes in the present study did not show these effects, and the ion absorption in plants need more explanation with other physiological measurements.

Heavy metal stress can disturb plant physiological processes, including photosynthesis, photoelectronic transfer and mineral nutrition absorption [39]. The response of hosts to abiotic stress such as heavy metals is very complicated. Endogenous hormones variation is one of the direct responses. Plant endogenous hormones are organic substances that regulate plant growth and development, which may be part of a signal-transduction pathway, and stimulate signal reactions for stress responses $[40,41]$. Studies have revealed that endogenous regulations (e.g., biosynthesis, transport, redistribution, and conjugation of plant hormones) play a crucial role during the acclimation process against stress [42,43]. Exogenous application of plant hormones has also been reported to enhance stress tolerance in plants affected by heavy metals [44-46]. In the present study, the four tested hormone $\left(\mathrm{GA}_{3}, \mathrm{CTK}\right.$, IAA and ABA) contents had significant variations under heavy metal stress. $\mathrm{Zn}^{2+}$ treatment increased the contents of $\mathrm{GA}_{3}$ and CTK and reduced the contents of ABA. $\mathrm{Cd}^{2+}$ treatment reduced the contents $\mathrm{GA}_{3}$ and IAA. Previous studies also revealed that $\mathrm{Cd}^{2+}$ treatment reduced the contents of IAA, ethylene and $\mathrm{GA}_{3}$ in Oryza sativa, which suggests that $\mathrm{Cd}^{2+}$ stress disturbs the biosynthesis of endogenous hormones [47]. These changes of endogenous hormones confirmed that the plants utilize hormones during stress response. Epichloë endophytes also have significant effects on endogenous hormones in plants and increased $\mathrm{GA}_{3}, \mathrm{CTK}$ and IAA contents and reduced ABA contents. These results were consistent with the previous studies that demonstrated Epichloë endophytes change hormones to improve host stress tolerance $[10,11,48]$. Bunyard and McInnis reported that E+ tall fescue plants produced significantly more ABA in response to drought stress than did E- plants [49]. Some glasshouse-based research has indicated a similar endophytE-enhancement of ABA concentration in tall fescue leaf tissue in response to drought [50]. Similar results were also observed in some Chinese native grasses like A. inebrians and F. sinensis. E+ Chinese wild rye (Leymus chinensis) plants have a higher SA content than E- plants, especially when they are exposed to B. sorokiniana and C. lunata [51]. Some endophytes have been reported to produce IAA and related indole compounds in culture [52,53]. The concentration increase in E+ plants may be also adjusted by the production of IAA and related compounds in planta by endophytes. Phytohormone production in planta may also induce the defense-related secondary metabolism in plants. However, far too little is known about the role that hormones may play in symbiosis and their direct effects on host fitness traits. The interaction of plants with heavy metal stresses are generally associated with immobilization in roots, ion balance, antioxidant defence, phytochelation, etc. More studies must be conducted to clarify these mechanisms.

The benefits that endophytes confer on plant health, and conversely, detrimental effects on animal health, are partially due to the production of biologically active alkaloids [54-56]. Two such important alkaloid classes are ergots and lolitrems (indole diterpenes), which cause neurotoxic effects on grazing and granivorous vertebrates. Two other classes of endophyte-derived alkaloids, peramine and lolines, are known to be highly active against invertebrates, yet have little or no activity against mammalian species [57]. Alkaloids may play roles in host biotic stress tolerance such as to pathogens and insects [58-61]. The contents of alkaloids varied with many factors, including endophytes, host genotypes and environmental conditions $[48,62]$. In the present study, the contents of lolitrem B increased under heavy metal stress, which suggest its association with stress tolerance. 
Our study showed that endophytes can promote the growth and development of F. sinensis under heavy metal stress. The mechanism that endophytes employed in improving host heavy metals stress tolerance included increasing the content of growth hormones such as IAA and $\mathrm{GA}_{3}$, reducing the content of $\mathrm{ABA}$ and adjusting the alkaloid contents. This study has hence provided more evidence about the Epichloë endophyte relationship with hosts, and extended the symbiosis research to more native species. These results are important for understanding of microbe-assisted phytoremediation. As the interaction between host-endophyte and abiotic stress tolerance is complicated, additional studies are being conducting to understand the mechanisms for endophyte-mediated heavy metal stress tolerance.

Author Contributions: P.T. and M.W. conceived and designed the experiments. M.W. contributed reagents, materials, and analysis tools. M.L. contributed to taking care of plants. P.T., M.W. and M.G. wrote the manuscript. All authors contributed to the manuscript and approved the submitted version. All authors have read and agreed to the published version of the manuscript.

Funding: The research reported here was funded by the National Nature Science Foundation of China $(31971768 ; 32061123004)$, the China Agriculture Research System (CARS-22 Green Manue) and Lanzhou University enterprisE-funded project \{(19)0439\}.

Institutional Review Board Statement: Not applicable.

Informed Consent Statement: Not applicable.

Data Availability Statement: Not applicable.

Acknowledgments: We would like to thank Zhongnan Nie (Department of Jobs, Precincts and Regions, VIC, Australia) for proofreading and polishing our manuscript.

Conflicts of Interest: The authors declare that they have no conflict of interest.

\section{References}

1. Nan, Z.B.; Li, C.J. Neotyphodium in native grasses in China and observations on endophyte/host interactions. In Proceedings of the 4th international Neotyphodium-Grass Interactions Symposium, Soest, Germany, 27-29 September 2000; pp. 41-50.

2. Li, C.; Ren, A.Z.; Gao, Y.B. Effect of endophyte infection on Zn resistance of tall fescue. Acta. Ecol. Sin. 2010, 30, 1684-1692. (In Chinese with English Abstract). [CrossRef]

3. Nan, Z.B. The grassland farming system and sustainable agricultural development in China. Grassl. Sci. 2005, 51, 15-19. [CrossRef]

4. Nan, Z.B. Incidence and distribution of endophytic fungi in seeds of some native and introduced grasses in China. Acta Prataculturae Sin. 1996, 5, 1-8. (In Chinese with English Abstract)

5. Nan, Z.B. Incidence and distribution of endophytic fungi in seedlings and plants of some native and introduced grasses in China. Acta Prataculturae Sin. 1996, 5, 13-17. (In Chinese with English Abstract)

6. Zhou, L.Y.; Li, C.J.; Zhang, X.X.; Johnson, R.; Bao, G.S.; Yao, X.; Chai, Q. Effects of cold shocked Epichloë infected Festuca sinensis on ergot alkaloid accumulation. Fungal Ecol. 2015, 14, 99-104. [CrossRef]

7. Zhou, L.Y.; Zhang, X.X.; Li, C.J.; Christensen, M.J.; Nan, Z.B. Antifungal activity and phytochemical investigation of the asexual endophyte of Epichloë sp. from Festuca sinensis. Sci. China Life Sci. 2015, 58, 821-826. [CrossRef] [PubMed]

8. Song, H.; Nan, Z.B.; Song, Q.Y.; Xia, C.; Li, X.Z.; Yao, X.; Xu, W.B.; Kuang, Y.; Tian, P.; Zhang, Q.P. Advances in research on Epichloë endophytes in Chinese native grasses. Front. Microbiol. 2016, 7, 1399. [CrossRef] [PubMed]

9. Tian, P.; Xu, W.B.; Li, C.J.; Song, H.; Wang, M.N.; Schardl, C.L.; Nan, Z.B. Phylogenetic relationship and taxonomy of a hybrid Epichloë species symbiotic with Festuca sinensis. Mycol. Prog. 2020, 19, 1069-1081. [CrossRef]

10. Saikkonen, K.; Wäli, P.; Helander, M.; Faeth, S.H. Evolution of endophyte-plant symbioses. Trends Plant Sci. 2004, 9, 275-280. [CrossRef] [PubMed]

11. Xia, C.; Li, N.N.; Zhang, Y.W.; Li, C.J.; Zhang, X.X.; Nan, Z.B. Role of Epichloë endophytes in defense responses of cool-season grasses to pathogens: A review. Plant Dis. 2018, 102, 2061-2073. [CrossRef]

12. Tian, P.; Kuang, Y.; Lin, W.H.; Wang, J.J.; Nan, Z.B. Shoot morphology and alkaloid content of Epichloë endophyte-Festuca sinensis associations. Crop. Pasture Sci. 2018, 69, 430-438. [CrossRef]

13. Peng, Q.Q.; Li, C.J.; Song, M.L.; Nan, Z.B. Effects of seed hydropriming on growth of Festuca sinensis infected with Neotyphodium endophyte. Fungal Ecol. 2013, 6, 83-91. [CrossRef]

14. Lin, W.H.; Wang, X.X.; Wang, J.J.; Nzabanita, C.; Xu, W.B.; Yang, L.; Xi, H.F.; Tian, P.; Wang, Y.B.; Li, M.M.; et al. Intra-and interspecific competition of Elymus nutans griseb. and Festuca sinensis keng. ex eb alexeev. infected by Epichloë endophyte. Bangladesh. J. Bot. 2018, 47, 699-709. 
15. Wang, J.J.; Zhou, Y.P.; Lin, W.H.; Li, M.M.; Wang, M.N.; Wang, Z.G.; Kuang, Y.; Tian, P. Effect of an Epichloë endophyte on adaptability to water stress in Festuca sinensis. Fungal Ecol. 2017, 30, 39-47. [CrossRef]

16. Masindi, V.; Muedi, K.L. Environmental contamination by heavy metals. Heavy Metals. 2018, 10, 115-132. [CrossRef]

17. Weyens, N.; Lelie, D.V.D.; Taghavi, S.; Vangronsveld, J. Phytoremediation: Lant-endophyte partnerships take the challenge. Curr. Opin. Biotechnol. 2009, 20, 248-254. [CrossRef]

18. Gong, Y.; Zhao, D.; Wang, Q. An overview of field-scale studies on remediation of soil contaminated with heavy metals and metalloids: Technical progress over the last decade. Water Res. 2018, 147, 440-460. [CrossRef]

19. Ayangbenro, A.S.; Babalolam, O.O. A new strategy for heavy metal polluted environments: A review of microbial biosorbents. Int. J. Environ. Res. Public Health 2017, 14, 94. [CrossRef]

20. Malinowski, D.P.; Belesky, D.P. Adaptations of endophyte-infected cool-season grasses to environmental stresses: Mechanisms of drought and mineral stress tolerance. Crop. Sci. 2000, 40, 923-940. [CrossRef]

21. Bonnet, M.; Camares, O.; Veisseire, P. Effects of zinc and influence of Acremonium lolii on growth parameters, chlorophyll a fluorescence and antioxidant enzyme activities of ryegrass (Lolium perenne L. cv Apollo). J. Exp. Bot. 2000, 51, 945-953. [CrossRef]

22. Ren, A.Z.; Gao, Y.B.; Zhang, L.; Xie, F. Effects of cadmium on growth parameters of endophyte-infected endophyte-free ryegrass. J. Plant Nutr. Soil Sci. 2006, 169, 857-860. [CrossRef]

23. Malinowski, D.P.; Belesky, D.P. Epichloë (formerly Neotyphodium) fungal endophytes increase adaptation of cool-season perennial grasses to environmental stresses. Acta Agrobot. 2019, 72, 1-26. [CrossRef]

24. Wang, Y.; Li, B.; Du, M.W.; Eneji, E.A.; Wang, B.M.; Duan, L.S.; Li, Z.H.; Tian, X.L. Mechanism of phytohormone involvement in feedback regulation of cotton leaf senescence induced by potassium deficiency. J. Exp. Bot. 2012, 63, 5887-5901. [CrossRef]

25. Fargaová, A. Toxicity comparison of some possible toxic metals (Cd, Cu, Pb, Se, $\mathrm{Zn}$ ) on young seedlings of Sinapis alba $\mathrm{L}$. Plant Soil Environ. 2004, 50, 33-38. [CrossRef]

26. Nusrat JalbaniArain, M.B.; Kazi, T.G.; Jamali, M.K.; Jalbani, N.; Afridi, H.I.; Baig, J.A. Speciation of heavy metals in untreated domestic waste water sludge by time saving BCR sequential extraction method. Environ. Sci. Health A 2007, 42, 649-659.

27. Sidhu, G.P.S.; Bali, A.S.; Singh, H.P.; Batish, D.R.; Kohli, R.K. Insights into the tolerance and phytoremediation potential of Coronopus didymus L.(Sm) grown under zinc stress. Chemosphere 2020, 244, 125350. [CrossRef]

28. Gallagher, R.T.; Hawkes, A.D.; Stewart, J.M. Rapid determination of the neurotoxin lolitrem B in perennial ryegrass by highperformance liquid chromatography with fluorescence detection. J. Chromatogr. A 1985, 321, 217-226. [CrossRef]

29. Ball, O.J.P.; Prestidge, R.A.; Sprosen, J.M. Interrelationships between Acremonium lolii, peramine, and lolitrem B in perennial ryegrass. Appl. Environ. Microbiol. 1995, 61, 1527-1533. [CrossRef]

30. Chaudhary, D.S.; Totawat, K.L. Zinc and phosphorus interaction on growth and nutrient uptake by wheat. Ann. Arid. Zone 1985, 24, 31-38.

31. Zhao, D.D. Studies on Growth and Resistance of Festuca Arundinacea under the Stress of Cd ${ }^{2+}$ and $\mathrm{Cd}^{2+}-\mathrm{Zn}^{2+}$; Sichuan Normal University: Chengdu, China, 2008. (In Chinese with English Abstract)

32. Nagajyoti, P.C.; Lee, K.D.; Sreekanth, T.V.M. Heavy metals, occurrence and toxicity for plants: A review. Environ. Chem. Lett. 2010, 8, 199-216. [CrossRef]

33. Zhang, X.X.; Li, C.J.; Nan, Z.B. Effects of cadmium stress on growth and anti-oxidative systems in Achnatherum inebrians, symbiotic with Neotyphodium gansuens. J. Hazard. Mater. 2010, 175, 703-709. [CrossRef] [PubMed]

34. Zhang, X.X.; Li, C.J.; Nan, Z.B. Effects of cadmium stress on seed germination and seedling growth of Elymus dahuricus infected with the Neotyphodium endophyte. Sci. China Life Sci. 2012, 55, 793-799. [CrossRef] [PubMed]

35. Malinowski, D.P.; Alloush, G.A.; Belesky, D.P. Evidence for chemical changes on the root surface of tall fescue in response to infection with the fungal endophyte Neotyphodium coenophialum. Plant Soil 1998, 205, 1-12. [CrossRef]

36. Malinowski, D.; Elesky, D.P. Infection with leaf fungal endophyte Neotyphodium coenophialum increase aluminium sequestration on root surfaces of tall fescue. J. Plant Nutr. 1999, 22, 1335-1349. [CrossRef]

37. Malinowski, D.P.; Zuo, H.; Belesky, D.P.; Alloush, G.A. Evidence for copper binding by extracellular root exudates of tall fescue but not perennial ryegrass infected with Neotyphodium spp. Endophytes. Plant Soil 2004, 267, 1-12. [CrossRef]

38. Creek, R.; Wade, G.L. Excretion of phenolic compounds from the roots of Festuca arundinacea, Eragrostis curvula, and Lespedeza striat. Trans. Ky. Acad. Sci. 1985, 46, 51-55.

39. Lanaras, T.; Moustakas, M.; Symeonidis, L.; Diamantoglou, S.; Karataglis, S. Plant metal content, growth responses and some photosynthetic measurements on field-cultivated wheat growing on ore bodies enriched in Cu. Physiol. Plant. 1993, 88, 307-314. [CrossRef]

40. Argueso, C.T.; Raines, T.; Kieber, J.J. Cytokinin signaling and transcriptional networks. Curr. Opin. Plant Biol. 2010, 13, 533-559. [CrossRef]

41. Qin, H.; Gu, Q.; Zhang, J.L.; Sun, L.; Kuppu, S.; Zhang, Y.Z.; Burow, M.; Payton, P.; Blumwald, E.; Zhang, H. Regulated expression of an Isopentenyltransferase Gene (IPT) in peanut significantly improves drought tolerance and increases yield under field conditions. Plant Cell Physiol. 2011, 52, 1904-1914. [CrossRef]

42. Wilkinson, S.; Kudoyarova, G.R.; Veselov, D.S.; Arkhipova, T.N.; Davies, W.J. Plant hormone interactions: Innovative targets for crop breeding and management. J. Exp. Bot. 2012, 63, 3499-3509. [CrossRef]

43. Srivastava, S.; Chiappetta, A.; Beatrice, M. Identification and profiling of arsenic stress-induced miRNAs in Brassica juncea. J. Exp. Bot. 2013, 64, 303-315. [CrossRef] 
44. Elobeid, M.; Go"bel, C.; Feussner, I.; Polle, A. Cadmium interferes with auxin physiology and lignification in Poplar. J. Exp. Bot. 2012, 63, 1413-1421. [CrossRef]

45. Zhu, X.F.; Jiang, T.; Wang, Z.W.; Lei, G.J.; Shi, Y.Z.; Li, G.X.; Zheng, S.J. Gibberellic acid alleviates cadmium toxicity by reducing nitric oxide accumulation and expression of IRT1 in Arabidopsis thaliana. J. Hazard. Mater. 2012, 239, 302-307. [CrossRef]

46. Krishnamurthy, A.; Rathinasabapathi, B. Auxin and its transport play a role in plant tolerance to arsenite-induced oxidative stress in Arabidopsis thaliana. Plant Cell Environ. 2013, 36, 1838-1849. [CrossRef]

47. Mei, Y.X. Effect of Endophyte Gao Y1-1 Infection on Endogenous Hormones and Organic Acids of Rice Seedlings under Cd and/or Al Stress; Shenyang Normal University: Shenyang, China, 2017. (In Chinese with English Abstract)

48. Battista, J.P.D.; Bouton, J.H.; Bacon, C.W.; Siegel, M.R. Rhizome and herbage production of endophyte-removed tall fescue clones and populations. Crop Sci. 1990, 82, 651-654. [CrossRef]

49. Bunyard, B.; Mclnnis, T.M. Evidence for elevated phytohormone levels in endophyte-infected tall fescue. In Proceedings of the International Symposium on Acremonium/Grass Interactions; Quisenberry, S.S., Joost, R.E., Eds.; Louisiana Agricultural Experiment Station: Baton Rouge, LA, USA, 1990; pp. 185-188.

50. Joost, R.E. Acremonium in fescue and ryegrass: Boon or bane? A review. J. Anim. Sci. 1995, 73, 881-888. [CrossRef] [PubMed]

51. Wang, X.Y.; Qin, J.H.; Chen, W.; Zhou, Y.; Ren, A.Z.; Gao, Y.B. Pathogen resistant advantage of endophyte-infected over endophyte-free Leymus chinensis is strengthened by pre-drought treatment. Eur. J. Plant Pathol. 2016, 144, 477-486. [CrossRef]

52. Battista, J.P.D.; Bacon, C.W.; Severson, R.F.; Plattner, R.D.; Bouton, J.H. Indole acetic acid production by the fungal endophyte of tall fescue. Agron. J. 1990, 82, 878-880. [CrossRef]

53. Yue, Q.; Miller, C.J.; White, J.F.; Richardson, M.D. Isolation and characterization of fungal inhibitors from Epichloë festucae. J. Agric. Food Chem. 2000, 48, 4687-4692. [CrossRef]

54. Bush, L.P.; Wilkinson, H.H.; Schardl, C.L. Bioprotective alkaloids of grass-fungal endophyte symbioses. Plant Physiol. 1997, 114, 1-7. [CrossRef] [PubMed]

55. Easton, H.S.; Latch, G.C.M.; Tapper, B.A.; Ball, O.J.P. Ryegrass host genetic control of contentrations of endophyte-derived alkaloids. Crop Sci. 2002, 42, 51-57. [PubMed]

56. Porter, J.K. Analysis of endophyte toxins: Fescue and other grasses toxic to livestock. J. Anim. Sci. 1995, 73, 871-880. [CrossRef]

57. Rowan, D.D.; Dymock, J.J.; Brimble, M.A. Effect of fungal metabolite peramine and analogs on feeding and development of Argentine stem weevil (Listronotus bonariensis). J. Chem. Ecol. 1990, 16, 1683-1695. [CrossRef] [PubMed]

58. Sabzalian, M.R.; Mirlohi, A.; Sharifnabi, B. Reaction to powdery mildew fungus, Blumeria graminis in endophyte-infected and endophyte-free tall and meadow fescues. Australas. Plant Pathol. 2012, 41, 565-572. [CrossRef]

59. Ma, M.Z.; Christensen, M.J.; Nan, Z.B. Effects of the endophyte Epichloë festucae var. lolii of perennial ryegrass (Lolium perenne) on indicators of oxidative stress from pathogenic fungi during seed germination and seedling growth. Eur. J. Plant Pathol. 2015, 141, 571-583. [CrossRef]

60. Popay, A.J.; Cotching, B.; Moorhead, A.; Ferguson, C.M. AR37 endophyte effects on porina and root aphid populations and ryegrass damage in the field. Proc. N. Zeal. Grassl Assoc. 2012, 74, 165-170. [CrossRef]

61. Matsukura, K.; Shiba, T.; Sasaki, T.; Yoshida, K.; Matsumura, M. Dynamics of Neotyphodium uncinatum and N-formylloline in Italian ryegrass, and their relation to insect resistance in the field. J. Appl. Microbiol. 2014, 116, 400-407. [CrossRef]

62. Rasmussen, S.; Parsons, A.J.; Bassett, S.; Christensen, M.J.; Hume, D.E.; Johnson, L.J.; Johnson, R.D.; Simpson, W.R.; Stacke, C.; Voisey, C.R. High nitrogen supply and carbohydrate content reduce fungal endophyte and alkaloid concentration in Lolium perenne. New Phytol. 2007, 173, 787-797. [CrossRef] 